Birlesik Dünya Arastırma

BD C CENTER

Innovasyon ve Yayıneılık Merkezi

\section{Cypriot Journal of Educational Sciences}

Volume 15, Issue 5, (2020) 1337 - 1353

www.cjes.eu

\title{
Educational communication skills and their problems among students of Princess Rahma university college at Al-Balqa applied university
}

Jamal Fawaz Mansour Al-Omari*,Educational Administration Balqa Applied University, Princess Rahma University College, https://orcid.org/0000-0001-7162-8493

\section{Suggested Citation:}

Al-Omari, J. F. M., (2020). Educational communication skills and their problems among students of Princess Rahma university college at Al-Balqa applied university. Cypriot Journal of Educational Science. 15(5), 1337 - 1353 https://doi.org/10.18844/cjes.v15i5.5172

Received from 19 July 2020; revised from 14 August 2020; accepted from October 12, 2020. (C)2020 Birlesik Dunya Yenilik Arastirma ve Yayincilik Merkezi. All rights reserved.

\begin{abstract}
The study aims to determine the reality of practicing educational communication skills among students at Princess Rahma University College (Al-Balqa Applied University) and the problems they face in practicing communication skills. The researcher used the descriptive method and a questionnaire consisting of two parts: the student's communication skills and the communication problems they face. The researcher used the statistical analysis program SPSS to extract the results which were applied to Cluster random sample of (145) male and female students with the percentage of $14 \%$ of the sample population. The results showed that the degree of practicing communication skills among the students at Princess Rahma University College was (moderate), while the most practiced skill was the speaking skill and the least was understanding and accepting others. the results also indicate that there are significant problems in educational communication among students of Princess Rahma University College that came to a high degree, where the field of the university environment came in the first place, followed by the field of study materials, while the field of faculty members came in the last place. The study found that there are statistically significant differences in the degree of the existence of educational communication problems among the students of Princess Rahma University College due to gender, academic level, and specialization variables. The research recommended constructing a new building for the college, providing classrooms with electronic educational devices, and developing the content of the study materials.
\end{abstract}

Keywords: communication problems, Princess Rahma University College, Al-Balqa Applied University.

\footnotetext{
* A ADDRESS FOR CORRESPONDENCE: Jamal Fawaz Mansour Al-Omari, Educational Administration Balqa Applied University, Princess Rahma University College.

This work has been carried out during sabbatical leave granted to the author (from Al-Balqa' Applied University) (BAU) during the academic year 2014/2015

E-mail address: drjamalalomari@yahoo.com / Tel.: 00962799097147/ 009666595124567
} 


\section{Introduction:}

Higher education institutions are among the most important educational institutions that prepare the human cadres that can achieve the requirements and the needs of the society, and which seek to provide its students with the required skills for performing their work effectively. In fact, what distinguishes a university from another is its ability to graduate individuals who can prove themselves in the field of their work as well as having an experienced faculty members who play a significant role in preparing the university student to face the challenges of the future with all the scientific, technical, organizational, and cultural developments it holds (Al-Qarni, 2007).

Some students may face certain difficulties related to communication, university adaptation, and academic challenges that may vary substantially from those they faced in secondary education due to different university environments and teaching methods.

Among the most important of these problems are the problems of communication and interaction with others which requires a degree of flexibility in communicating, adapting, and dealing with the developments and requirements of university study. Many studies including the study of Al-Shehri (2014) revealed the existence of some academic problems that students face, and which affect their academic achievement and motivation to learn. These difficulties constitute obstacles to their academic progress (AlShehri, 2014.)

Communication is an art and science compared to other sciences and is one of the basic processes in building human relationships. It is an interactive, reciprocal process of communicating a message through a specific means to achieve a specific goal. Psychologists, sociology, administration, and education have defined the word " communication". Communication is derived from the Latin origin (Communis) which means "the exchange of information, ideas or opinions by speech." Or by "writing or pointing. " Communication can be divided into two basic types: verbal communication that is made by using the spoken language and phonemic symbols, and non-verbal communication based on the use of signs, symbols, and body language (Hariri, 2018).

One of the most important skills of the twenty-first century is mastering communication skills because it strengthens the social relationships, contributing to the transmission of information, feelings, and attitudes between the sender and the receiver. The main communication elements- : 1 . The sender.

2.The receiver.

3.The message.

4.Communication tool.

5.The communication channel.

\section{Confusion}

\subsection{Communication barriers}

Communicate does not happen without existence problems or obstacles. Some sources of confusion or the irregular flow of the message may appear because of several factors. Among the most important of these factors that reduce loyalty and faith in the message among the facility's employees are the following:

- Lack of attention of the receiver of the message to its contents

- Lack of accurate understanding of the intended message, whether by the receiver or the source

- Using words in the message that have different meanings and indications to other people.

- Time pressure for both the sender and the receiver.

- The impact of receiver personal judgment that may affect the success of the communication process

To overcome the impact of these difficulties on the communication process, the following should be considered: 
1 -Providing information in a manner consistent with the person's desires, as the person accepts or denies the information, according to whether it is consistent with his needs or not. Therefore, the administration should understand those needs and desires and design communication methods accordingly.

\section{2 -Providing information in small units}

3 -Providing the opportunity to the person to whom the information is sent to explain his view of the sent information to ensure that the intended information "message" has been received correctly.

The main goal is to deliver the largest amount of accurate information to workers without delay or confusion. As any confusion in understanding the intended message may spread rumors and adversely affect morale and productive efficiency. Through reviewing previous studies related to the research topic "communication skills" and its problems, it was found that some have addressed the effect of communication skills on the students' academic achievements, and some have touched on the role of the curriculum in promoting the culture of communication.

Al-Qabbani and Al-Yahya (2019) conducted a study entitled "The role of social networking sites in enhancing dialogue skills among university students". The researchers used the descriptive approach and a questionnaire consisting of these domains the role of social media (i.e. Twitter \& WhatsApp) in promoting effective communication skills and the role of social media (i.e. Twitter \& WhatsApp) in promoting the persuasion and influence skill. The study sample consisted of (8239) female students at Prince Sattam Bin Abdulaziz University- Alkharj branch.

The study found that statistically significant differences of ( 0.05 and less) in the participants' responses to the role of Twitter \& WhatsApp in promoting effective communication and persuasion and influence skills based on college variables. And that there were no statistically significant differences at the level of ( 0.05 and less) in the participants' responses to the role of social media (i.e. Twitter \& WhatsApp) in promoting effective communication and persuasion and influence.

In 2019, Ziadat, Abu-Nair, and Abu Sameha examined the mechanisms and developmental strategies for teaching thinking skills in the Jordan universities from the faculty members' point of view. Also aimed to identify the influence of academic rank in shaping the mechanisms and the teaching strategies. The researcher used the descriptive method. The random sample consisted of (85) faculty members from Al-Balqa Applied University. The result of the study showed that there were no statistically significant differences in the response of the study sample attributable to the variable "teaching experience and academic rank (Abu- Nair \&Ziadat\&Abu Samyha,2019.)

Liaw(2019)aimed to investigate the effects of using open social VR for university English as a foreign language (EFL) learners' intercultural communication learning. The project followed two stages: (1) designing activities to practice various language-learning tasks with their peers; (2) implementing an open social VR environment for intercultural interactions. The researcher collects the data from different sources, including surveys, video-recordings, and oral reports. The findings showed that the participants identified the social and physical presence afforded by the VR environment positively. Occurrences of intercultural communicative competence were identified in the participants' interactions with international interlocutors in open social VR spaces. And that the participants were unsure of the effectiveness of the approach when practicing language tasks with their peers.

Amna( 2019) conducted a study sought to detect the extent of the disparity of using social media among a sample of students of Al-Fashir University - Faculty of Education. It also aimed to detect the differences according to gender, specialization, and age variables. The researcher used the descriptive corelational method and social media measure prepared by Algamdi (2017). The sample reached 300 students randomly class chosen and who represent science and humanitarian Departments. The findings disclosed that there are variables in using the social media whereas What-sap and Face-book reached the highest percentage; 
then the Black-berry, Twitter, Instagram and chat; there are no significant statistical differences in using the social media according to gender and specialty variable; there are variables according to age. The study reached some recommendations and suggestions based on the findings that are mentioned at the end of the study.

Shuqair (2018) addressed the degree of using social media among students of the Faculty of Education at the University of Damascus, the common psychological problems the students face, and the relationship between the use of social media and the psychological problems. The researcher used the descriptive approach and two tools: (a questionnaire on the use of social media networks, and a psychological problems Scale). The sample consist of (400) students in the Faculty of Education at the University of Damascus. Among the most important findings of the research showed: 1) A positive correlation relationship with statistical significance between the use of social networks and psychological problems among students of the Faculty of Education at the University of Damascus. 2) Statistically significant differences between the mean of responses of the respondents to the questionnaire of using social media networks referring to the variable years of using communication networks for the benefit of students who have been using communication networks for 5 years or more. 3) Statistically significant differences between the average responses of the respondents for using social media networks according to the variable of the school year in favor of first-year students. 4) The presence of statistically significant differences between the average responses of the research sample on the scale of psychological problems according to the variable years of using communication networks for the benefit of students who have been using communication networks for 5 years or more.

Al-Shobaki and others (2017) conducted a study aimed at identifying the educational communication skills practice by the university professor from the viewpoint of students at the Faculty of Arts and identifying the ratios of teachers' practice of educational communication skills in the departments of the Faculty of Arts. The research sample consisted of (65) students. The researchers built a questionnaire divided into (9) fields. The research reached the following results: that the skills practiced by the university professor reached (57) skills according to the questionnaire items, and these results indicate that educational communication skills exist and are practiced by most professors, while the skills that are practiced to a small degree amounted to (11) paragraphs, and the research also found that A difference in the percentage of teachers teaching educational communication skills, and the percentage ranged between $(87 \%-56 \%)$ and this percentage is good.

Ibrahim's study in 2016 aimed to display a scale entitled "Social problems of university students, Sultan Qaboos". The sample consisted of two groups; group(1) consisted of(330) students (108 males and 215 females) from Sultan Qaboos University students who are studying in the spring of 2015, distributed among the various colleges of the university (9) colleges, and the group (2) included (593) students (194 males and 399 females). The study tool was a scale of social problems for university students. The study was divided into five components: academic problems, group life problems, psychological, behavioral, and social problems, social networking sites, and leisure time problems.

The results of the study indicated the existence of some problems among students of Sultan Qaboos University in the form of problems of social networking sites and free time, psychological and social problems, academic achievement problems, and societal problems. The study recommended studying the relationship between social problems of Sultan Qaboos University students and their relationship to some variables such as GPA, academic specialization, residential area, and age group (Ibrahim, 2016.)

Al-Dimati (2016) aimed to explain some psychological problems and their relationship with the use of social media networks, and to clarify the relationship between some variables such as (age, number of hours for using the networks per day, the time to start using the Internet, the educational level of the father and monthly income) and the appearance of these psychological problems in addition to determining the relationship between these problems. The results showed that there were no statistically significant differences at the level of $(0.05)$ between the appearance of some psychological problems (aggressive 
behavior, psychological unity, psychological restlessness) and Social network servers attributable to the age variable, or the time to start using the Internet ( 2 years ago, 3 years ago, 4 years or more).

Al-Adra and Abu Arqoub (2015) conducted a study to explain the communication barriers which faces the students at the University of Jordan from their perspective, and they reached the following results: The degree of communication barriers for the university students on the six dimensions were moderate and the highest obstacles resulted from the sender and the communication channel. The result also illustrated that there were no significant differences in other dimensions, such as gender, college, and educational level. Some previous studies have discussed knowledge of communication skills, its nature, and its problems, while others addressed the students' academic problems and the effect of the curricula in enhancing the culture of communication. The results of some studies revealed the types of problems facing universities in educational communication, their degree, estimates, and quality varied.

In brief, although the previous studies differ in terms of their methodology and sample, they all have the same goal that is to raise the level of higher education institutions; through evaluating their programs, raising the quality of their outputs and learning environment.

The current research has benefited from the previous studies in preparing the theoretical framework, building the research tool, interpreting the results. Where it differed from previous studies in terms of the place where it was applied, the communication skills it addresses, and in identifying the problems that the students met when communicating with each other.

The researcher has noticed that shortage of local studies that dealt with the issue of communication skills among students at the university which is shown in students' behaviors ( altercations, verbal squabbles, and student disputes) during recent years that arise between them due to the difference in their views of some issues. These differences hinder students 'proper interaction, social growth, and their active involvement in university life. Actually, some universities didn't have enough indicative programs which strengthen students' communication skills, which requires conducting more research in the area of communication skills. Hence, this research came to identify the degree of educational communication skills practiced by the students in Princess Rahma University College at Al-Balqa Applied University from the viewpoint of the students themselves and to detect the problem they face in this area.

\subsection{Research problem and questions:}

Educational communication is a central issue that occupies the forefront of the media, educational, artistic and cultural interest, and it is one of the most central skills that university education should enhance, as poor communication skills between students at this stage lead to the emergence of educational problems that affect the efficiency of the educational process at one hand and the skills of the graduated students in another hand. The researcher has noted through his work at Al-Balqa Applied University that there are many problems affecting students' interaction with each other and their expected achievements in the communication process. These problems come from different basic sources including the university environment, services, and facilities that must be provided for achieving a successful teaching and learning process. On the other hand, the faculty members, and academic decisions.

Many students claim that there are certain difficulties arise between them or between students and university teachers that resulted from their weak mastering of communication skills. Hence, this study came to demonstrate the reality of practicing the communication skills and their problems amongst students of Princess Rahma University College at Al-Balqa Applied University through answering the following main question: What is the reality of practicing communication skills and their problems among students of Princess Rahma University College at Al-Balqa Applied University? 
This question is divided into the following sub-questions:

1) What is the reality of practicing communication skills among Princess Rahma University College students from their point of view?

2) What are the communication problems that face the students at Princess Rahma University College?

3) Are there significant differences in the responses of Princess Rahma University College students to the degree of the existence of communication problems from their viewpoint attributable to variables: gender, academic level, specialization?

\subsection{Research objectives:}

The research aims to demonstrate the reality of practicing communication skills and their problems among students of Princess Rahma University College at Al-Balqa Applied University and to reveal the differences, if any, in the responses of students at Princess Rahma University College of the educational communication problems according to variables: gender, academic level, specialization.

\subsection{Research importance:}

The importance of the research lies in two aspects:

1- Theoretical importance, which lies in the subject of research through studying educational communication problems among students, and the degree of the availability of the communication skills among students of Princess Rahma University College, which may benefit the Dean of Princess Rahma University College in identifying the problems of educational communication among students, and finding appropriate solutions.

2- The practical importance lies in the expected findings of the research, which can be used to work on improving effective communication between students according to the reality of the university environment.

3- To suggest useful solutions to overcome the communication problems of students of Princess Rahma University College at Al-Balqa Applied University.

\section{Methods and Procedures}

2.1 Research Methodology: The researcher used the descriptive survey method to achieve the objectives of this research.

2.2 Research population: The study population covered (145) students of Princess Rahma University College in the academic year 2018-2019 as shown in Table (1).

Table (1) Distribution of members of the research community by gender and specialization

\begin{tabular}{llll}
\hline variable & Gender & & Total \\
& Male & Female & 82 \\
\hline Social Service & 301 & 82 & 391 \\
Special Education & 127 & 147 & 274 \\
Delinquency and & 163 & 165 & 328 \\
Crime & & & \\
Total & 993 & & \\
\hline
\end{tabular}


2.3 The research sample: The research sample was chosen in a cluster random way, consisting of (145) male and female students representing the research variables with a percentage of $14 \%$ according to the statistics issued by the admission and registration unit.

\subsection{Research tools:}

The researcher used two tools to answer the research questions, as follows:

A) The communication skills Scale of Jordanian university students, prepared by the researcher (Hamidat, 2009) which consisted of (32) items that measure four basic skills speaking skills, listening skills, understanding others, and managing emotions researcher has checked the validity of the questionnaire as follows:

1- The content validity: the scale and its (54) items were presented in its initial form to specialists arbitrators in the field of measurement and evaluation to verify the clarity of the items and their suitability to the fields of measurement. After reviewing the opinions of the arbitrators, the number of items became (33) items.

2- The stability of the questionnaire:

To confirm the consistency of the questionnaire, the questionnaire was applied to a sample of (20) students from outside the research sample. The method of test-retest was applied with a difference of two weeks between the first and second applications and the Pearson correlation coefficient was calculated between the first application and the second application and the value of the stability factor (0.89), which is considered acceptable.

B) A special questionnaire that included (60) items that were developed to measure the communication problems of students consisting of three areas: the university environment, the teaching staff, and study materials. This tool was developed based on the previous studies that were conducted in the same subject of this research such as the study of Murtaja (2013). The questionnaire was distributed to the research population. (145) questionnaires were retrieved out of (162) and by $90 \%$, which can be relied upon to generalize it to the research population. The researcher used a triple scale: (high, moderate, and low) to identify communication problems. The triple scale is designed as follows: $2.50-3.00$ high, 1.50 to 2.49 moderate, and from 1.00 to 1.49 low.

1- Face validity of the questionnaire, the researcher presented it to a group of faculty members who specialize in the field of educational administration in some Jordanian universities, where they were asked to check the appropriateness of the questionnaire items to the field they measured and the language cohesion. Considering their comments, some items were excluded, and others were modified, the final form of the questionnaire consisted of (60)items.

2- The reliability of the tool: The researcher checked the reliability of the questionnaire by applying it to an exploratory sample where the Alpha Cronbach coefficient was calculated for the internal consistency its value reached (0.87), which is a high coefficient and is considered acceptable.

\subsection{Procedural definitions of search terms:}

The search includes and defines the following terms:

Communication problems: All that the students of Princess Rahma University College object to in the educational process in the following fields: the university environment, curricula, faculty, and communication skills that affect their achievement of scientific information.

Communication skills: The individual's ability to successfully send and receive messages and is measured according to the degree to which students have answered the prepared scale. 
Verbal speaking and skill are the individual's ability to successfully deliver a message to the future during the verbal communication process.

Listening skill (listening): The ability of an individual to listen in a way that enables him to understand the sender's message, whether verbal or non-verbal.

The skill of managing situations and emotions: The individual's ability to control his feelings, emotions, and emotions in different situations.

- The skill of understanding and accepting others: the individual's ability to know the content of the message addressed to him and to show and control the positions, feelings, and emotions in different situations.

University environment: The university climate in which students live during their academic years and includes the physical and human factors that surround it. The researcher adopted this definition as a procedural definition of the term in the research.

Princess Rahma University College students: They are students registered to study at Princess Rahma University College to obtain a bachelor's degree and a diploma in educational and social disciplines during the 2013-2014 academic year.

Al-Balqa Applied University: A Jordanian public university located in the city of Salt, $47 \mathrm{~km}$ from the capital, Amman, established in 1997 by royal decree in the Salt region (www.bau.edu.jo)

\subsection{Research procedures}

The researcher followed the following procedures:

1- Reviewing theoretical literature and previous studies related to the research topic.

2- Developing the research tools by referring to previous studies.

3- Defining the sample by referring to the statistics issued by the Administration of Admission and Registration.

4- Applying the research tools to the sample members by using two ways electronically( electronic questionnaire) or directly (hard copy questionnaire) at college.

5- Through statistical analysis using the SPSS program to extract the results.

\subsection{Statistical research methods:}

To achieve the research objectives, analyses data, and answer research questions, the following statistical methods were used:

1) Mean and Standard Deviations were used to determine the order of items according to the answers of the research sample to answer the first question.

2) The Alpha Cronbach coefficient to determine the reliability of research tools.

3) Single-contrast analysis to answer the second question.

\section{Results and discussion}

A) The results of the first question: What is the reality of practicing communication skills among Princess Rahma University College students from their point of view?

To answer this question, the researcher calculated the mean and standard deviations as shown in Table (2). 
Table (2) standard averages and deviations for each paragraph of the areas of communication skills:

\begin{tabular}{|c|c|c|c|c|}
\hline NO. & Items & Mean & SD & Rank \\
\hline 1. & I quickly try to end discussions that do not interest me & 4.76 & 0.489 & high \\
\hline 2. & I wait for the speaker to finish talking before judging his words & 4.63 & 0.759 & high \\
\hline 3. & $\begin{array}{l}\text { I encourage the speaker to complete his speech by using specific } \\
\text { expressions }\end{array}$ & 4.61 & 0.815 & high \\
\hline 4. & When I am in an official interview, I choose phrases carefully & 4.58 & 0.801 & high \\
\hline 5. & I end my interviews with closing sentences & 4.51 & 0.769 & high \\
\hline 6. & I avoid discussing sensitive topics & 4.50 & 0.751 & high \\
\hline 7. & I can confront someone who hurt my feelings & 4.39 & 0.848 & high \\
\hline 8. & $\begin{array}{l}\text { I feel that the people I speak with think that I cannot understand } \\
\text { them well }\end{array}$ & 4.39 & 0.881 & high \\
\hline 9. & When I criticize someone, I mention their behavior and actions & 4.39 & 1.145 & high \\
\hline 10. & $\begin{array}{l}\text { I can solve my problems with others without losing control of my } \\
\text { emotions }\end{array}$ & 4,38 & 0.926 & high \\
\hline 11. & $\begin{array}{l}\text { I prefer not to convince the person who caused it of something } \\
\text { difficult to believe }\end{array}$ & 4,38 & 0.98 & high \\
\hline 12. & $\begin{array}{l}\text { I review myself to make sure that I understand what others are trying } \\
\text { to convey to me }\end{array}$ & 4,72 & 0.13 & $\begin{array}{l}\text { moderat } \\
\text { e }\end{array}$ \\
\hline 13. & I can tolerate others & 4,61 & 0.16 & high \\
\hline 14. & I do my best to understand others & 4.78 & 0.333 & $\begin{array}{l}\text { moderat } \\
\text { e }\end{array}$ \\
\hline 15. & I talk a little slowly and I stop to give others a chance to talk & 4.17 & 1.021 & high \\
\hline 16. & I can control my mood when it is upset & 3.93 & 0.256 & $\begin{array}{l}\text { moderat } \\
\mathrm{e}\end{array}$ \\
\hline 17. & Consider how my words and actions will affect others & 2.93 & 0.256 & $\begin{array}{l}\text { moderat } \\
\text { e }\end{array}$ \\
\hline 18. & $\begin{array}{l}\text { When I listen to the person speaking, I can communicate with them } \\
\text { with eye movements }\end{array}$ & 3.92 & 0.278 & $\begin{array}{l}\text { moderat } \\
\mathrm{e}\end{array}$ \\
\hline 19. & $\begin{array}{l}\text { I nod my head when I listen to someone talking as a sign of agreeing } \\
\text { to what he says }\end{array}$ & 3.89 & 0.316 & $\begin{array}{l}\text { moderat } \\
\mathrm{e}\end{array}$ \\
\hline 20. & $\begin{array}{l}\text { When I want to end a discussion, I use concluding sentences (such as } \\
\text { I enjoy talking to you) }\end{array}$ & 3.89 & 0.316 & $\begin{array}{l}\text { moderat } \\
\text { e }\end{array}$ \\
\hline 21. & I can estimate what others are aiming at by looking at them. & 3.89 & 0.316 & $\begin{array}{l}\text { moderat } \\
\text { e }\end{array}$ \\
\hline 22. & I smile when others talk & 3.79 & 0.165 & low \\
\hline 23. & I move my eyebrows when I do not agree with the speaker & 3.77 & 0.419 & low \\
\hline 24. & When I talk, I try to be simple and short sentences & 3.75 & 0.436 & $\begin{array}{l}\text { moderat } \\
\text { e }\end{array}$ \\
\hline 25. & I use the people names when I speak to them & 3.75 & 0.436 & $\begin{array}{l}\text { moderat } \\
\mathrm{e}\end{array}$ \\
\hline 26. & I give full attention to the person who talks to me & 3.74 & 0.443 & $\begin{array}{l}\text { moderat } \\
\text { e }\end{array}$ \\
\hline 27. & If someone apologizes to me for a mistake, I accept his apology & 3.83 & 0.333 & $\begin{array}{l}\text { moderat } \\
\text { e }\end{array}$ \\
\hline 28. & $\begin{array}{l}\text { I pay attention to the appropriateness of tone of my voice to the } \\
\text { subject of my speech }\end{array}$ & 3.78 & 0.165 & $\begin{array}{l}\text { moderat } \\
\mathrm{e}\end{array}$ \\
\hline
\end{tabular}




\begin{tabular}{lllll}
\hline 29. I give my opinion and comments on what others say & 3.63 & 0.419 & moderat \\
& & & & e \\
30. I can understand other people's points of view & 2.90 & 0.436 & low \\
31. If I mistake someone, I apologize for it & 2.41 & 0.436 & low \\
32. I realize what other gestures indicate & 1.66 & 0.443 & Very low \\
Total & 3.99 & .0 .52 & moderat \\
& & .0 .52 & & e \\
\hline
\end{tabular}

Table (2) shows that the overall degree of practicing communication skills for Princess Rahma College students is moderate. The degrees ranged between low- high with means $(4.78-1.66)$. The degrees of some items ranged between (moderate-low) which indicates a significant problem in practicing communication skills among the students at Princess Rahma College. To identify the degree of practicing communication skills among Princess Rahma University College students for each of the communication skills separately, the researcher used arithmetic mean, the standard deviations for each skill according to the scale as indicated in Table (3):

Table (3) the degree of availability of communication skills for students of Princess Rahma University College:

\begin{tabular}{lllll}
\hline NO. & Skills & Mean & SD & Rank \\
\hline 1 & Speak and verbal expression & 3.11 & 0.316 & \\
2 & Listening skills & 3,10 & 0.333 & \\
3 & Managing emotions & 2.97 & 0.165 \\
4 & Understanding others & 2.72 & 0.419 \\
Total & & 3.99 & moderate
\end{tabular}

Table (3) shows that the most communication skill practiced among students of Princess Rahma University was the skill of speaking and verbal expression followed by the listening skills, managing emotions, and understanding others with the means (3.11), (3.10), (2.97) and (2.72) respectively. The results in Table (3) indicate that the total level of the degree of practicing communication skills among Princess Rahma University College students reached $(2,98)$ and it is a moderate degree. This result is in line with the results of these studies (Liaw, 2019), (Ziadat, Abu-Nair and Abu Sameha, 2019), (Kabbani and Yahya, 2019) and (Dumiati, 2016.)

B) The results of the second question and its discussion: What are the problems of educational communication among students of Princess Rahma University College at Al-Balqa Applied University? To answer this question, the researcher calculated the arithmetic averages and standard deviations, and table (4) shows that:

Table 4 standard averages and deviations for each of the research areas

\begin{tabular}{llllll}
\hline NO. & Items & Mean & SD & Rank \\
& & & & \\
\hline 1. & The university provides the necessary services for students & 2.82 & .93 & high \\
2. & The university provides a comfortable atmosphere for studying & 2.62 & .87 & high \\
3. & The electronics means are not available in classrooms & 2.57 & .67 & high \\
4. & The university lacks a social and psychological or a counselor & 2.55 & .63 & high \\
\hline
\end{tabular}


5. Classrooms do not match the numbers of students enrolled in the $\begin{array}{llll}2.50 & .64 & \text { high }\end{array}$ university

6. Lack of activities and training in the subjects

$2.47 \quad .64 \quad$ high

7. External noise is frequent outside the classroom

$2.47 \quad .67 \quad$ high

8. The university library lacks many books in various types of science and $2.45 \quad .78$ high scientific knowledge

9. The university building is not appropriate to be a study center

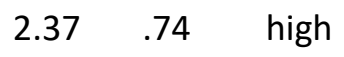

10. Student seating is not appropriate

$2.37 \quad .86 \quad$ high

11. There are no practical laboratories in the college in the field of $2.35 \quad .97 \quad$ high specialization

12. The college lacks a hall for student activities

$2.32 \quad .79 \quad$ high

13. The cafeteria is suitable for dining

$2.32 \quad .79$

high

14. Scientific laboratories lack the equipment and materials to conduct $2.32 \quad .85$ high experiments

15. The buildings obstruct student movement

$2.27 \quad 90 \quad$ moderate

16. Lack of feedback for the subjects

$2.27 .96 \quad$ moderate

17. Teaching depends on lecture-style permanently

2.25 .66 moderate

18. Study courses do not meet individual differences

$2.22 \quad 69$ moderate

19 Classrooms are poorly ventilated and lit

$2.22 \quad .86 \quad$ moderate

20 Study courses are long and repetitive

2.22 .91 moderate

21 The university site is not suitable for student accommodation

$2.20 \quad .75$

moderate

22 The course material is not logically formed

$2.21 \quad .75$

moderate

23 The course material is full of useless information

$2.20 \quad .85$

moderate

24 The interest of the course author in linking previous ideas with

$2.17 \quad .84$

moderate subsequent ideas is weak

25 The practical materials are presented in a theoretical way

$2.15 .76 \quad$ moderate

26 Printing of scientific material is not clear

2.15 .92 moderate

27 The college copiers do not meet the students' need

$2.10 .90 \quad$ moderate

28 The course language is difficult and unclear

$2.09 \quad .72$ moderate

29 The presence of the teaching staff office hours is little

$2.08 \quad .82 \quad$ moderate

30 Limited time for some school subjects

$2.07 \quad .85$

moderate

31 The scarcity of pictures, shapes, and drawings in the academic courses

$2.06 \quad .91$

moderate

32 The interest of the curricula in summarizing the basic ideas is weak

$2.05 \quad .76$

moderate

33 The use of modern technology is ineffective

$2.04 \quad .84$

moderate 


\begin{tabular}{|c|c|c|c|c|}
\hline 34 & The paper used to print the course is poor & 2.03 & .84 & moderate \\
\hline 35 & The internet at the university is slow & 2.02 & .90 & moderate \\
\hline 36 & The ability to control scientific discussions is weak & 2.01 & .69 & moderate \\
\hline 37 & The computers in the labs are ineffective & 2.00 & .89 & moderate \\
\hline 38 & The subjects depend on memorization & 1.99 & .89 & Moderate \\
\hline 39 & $\begin{array}{l}\text { The course's author did not write the content in a way to stimulate the } \\
\text { learner's interests and self-motivation }\end{array}$ & 1.95 & .84 & Moderate \\
\hline 40 & $\begin{array}{l}\text { The faculty member communication with students via the Internet is } \\
\text { limited }\end{array}$ & 1.92 & .87 & Moderate \\
\hline 41 & The number of computers required for e-learning is not enough & 1.87 & .87 & Moderate \\
\hline 42 & It rarely works to solve problems facing students & 1.85 & 61 & Moderate \\
\hline 43 & The faculty member sums up a few points in the lecture & 1.84 & .86 & Moderate \\
\hline 44 & $\begin{array}{l}\text { The faculty member provides information without making an } \\
\text { introduction }\end{array}$ & 1.82 & .78 & Moderate \\
\hline 45 & $\begin{array}{l}\text { The faculty member faces difficulties in trying to convince students by } \\
\text { using scientific argument and the proof }\end{array}$ & 1.81 & .65 & Moderate \\
\hline 46 & The university has the appropriate services & 1.80 & .76 & Moderate \\
\hline 47 & The faculty member has a weak ability to clarify information & 1.79 & .79 & Moderate \\
\hline 48 & The faculty member does not make eye contacts with all students & 1.77 & .91 & Moderate \\
\hline 49 & The faculty member rarely uses facial expressions during a lecture & 1.77 & .75 & Moderate \\
\hline 50 & The faculty member is unable to present the main ideas of the lecture & 1.74 & .73 & Moderate \\
\hline 51 & The inefficiency of the medical clinic and first aid & 1.72 & 0.78 & Moderate \\
\hline 52 & $\begin{array}{l}\text { The faculty member expresses his opinion and does not listen to } \\
\text { students' opinions and questions }\end{array}$ & 1.67 & 61 & Moderate \\
\hline 53 & $\begin{array}{l}\text { The faculty member rarely uses graphics and figures to clarify the } \\
\text { concepts and terms }\end{array}$ & 1.65 & .89 & Moderate \\
\hline 54 & The faculty member voice is weak and unheard & 1.64 & .88 & Moderate \\
\hline 55 & The faculty member speaks in an incorrect language & 1.62 & .76 & Moderate \\
\hline 56 & The university has green spaces for students to sit-in & 1.57 & .75 & Moderate \\
\hline 57 & The faculty member presents ideas in an illogical way & 1.55 & .77 & Moderate \\
\hline 58 & Library staff ignore student assistance & 1.44 & .71 & A few \\
\hline 59 & The faculty member does not consider the students' circumstances & 1.10 & .70 & A few \\
\hline 60 & The faculty member talks in a bored and boring style & 1.09 & 0.72 & A few \\
\hline \multicolumn{2}{|c|}{ The total average } & 2.07 & 0.80 & moderate \\
\hline
\end{tabular}


Table (4) shows the following:

The overall mean is (2.07) with a standard deviation (0.80), which indicates that there are some communication problems at a moderate degree among students of Princess Rahma University College. The results showed the following:

The following items $(22,23,31,32.34,35,36,39,40,41,43,53)$ respectively came at a (high) degree due to problems in communication between students at Princess Rahma University College, where the items that came at the (moderate) degree are (1-9), items (11-27), and items (44-60) which represents the field of faculty members. This indicates that the college contributes to providing communication relations between students and the teaching staff with a moderate degree. The items that came in a low degree are $(10,8,9)$ and they are among the fields of the faculty members. To find out the degree of educational communication problems according to the three areas of the research, the results showed the following:

Table 5: The mean and standard deviations for the three search fields are in descending order of the tool as a whole:

\begin{tabular}{lllll}
\hline NO. & Skills & Mean & $\begin{array}{l}\text { Standard } \\
\text { Deviation }\end{array}$ & Rank \\
\hline 1 & & & 0.84 & Moderate \\
2 & University environment & 2.68 & 0.91 & Moderate \\
3 & Courses & 2.60 & 0.99 & Moderate \\
Overall average & Teaching staff & 2.50 & 0.91 & Moderate \\
\hline
\end{tabular}

Table (5) shows that there are significant differences in the means between the three fields of research, where the university environment came in the first place followed by the academic subjects, and the faculty members came the last place. The researcher attributes this result to the weakness of the financial capabilities of Princess Rahma University College and the lack of interest in establishing a new building for the college which was built about forty years ago. This also may be attributed to the failure of the university to allocate the necessary funding for the building, as well as the lack of interest of the local community in finding a new building for the college compatible with aspirations and scientific developments according to the criteria of academic accreditation and quality assurance, and that some of the college buildings were not originally constructed as university buildings, they were a social development center affiliated with the Ministry of Social Development, and do not accommodate large numbers of students as the classrooms in social development centers, or regular schools are designed to accommodate about (25) students, but the number of students enrolled in the university every year exceeds this number, which compels the university to schedule lectures according to the availability of unoccupied classrooms. These results are consistent with the study of (Liaw, 2019) and (AbuNair \& Ziadat \& Abu Samyha, 2019), (Qabbani and Yahya studies, 2019) and (Damietta,2016.) C) The results of the third sub-question: Are there statistically significant differences in the degree of educational communication problems among responses of Princess Rahma University College students due to gender, academic level, or specialization?

To answer this question, the researcher used the T-test to reveal the significance of gender differences, and Table 6 shows that: 
Table (6): T-test results show the differences in communication problems among responses of Princess Rahma University College students due to the gender variable

\begin{tabular}{llllll}
\hline Domains & Mean & & Mean & SD & Sig \\
& & & & \\
\hline Academic staff & Male & 69 & 45.95 & 4.58 & 0.05 \\
& female & 79 & 47.62 & 5.92 & \\
University & Male & 69 & 64.07 & 5.16 & 0.05 \\
environment & female & 79 & 45.95 & 5.61 & \\
Academic courses & Male & 69 & 47.62 & 4.99 & 0.05 \\
& female & & 64.07 & 6.10 & \\
Overall average & Male & 69 & 157.64 & 17.63 & 0.05 \\
& female & 79 & 157.64 & 14.73 & \\
\hline
\end{tabular}

Table (6) indicates that there are statistically significant differences attributable to the gender variable (male, female), which were in favor of males. The researcher attributes this to the large number of life requirements needed by males compared to females. It can also be attributed to the social and psychological pressures that male is exposed to in terms of the availability of employment opportunities which reduces their interest in communication compared to females who are more motivating towards the academic achievement and this appears through the academic GPAs, and this result is consistent with the study of each: (Liaw, 2019),\&,( Ziadat, Abu-Nair and Abu Sameha, 2019), (Qabbani and Al-Yahya Study,2019) and (Dumiati, 2016.) Concerning the academic level and specialization for students, the researcher used the method of ANOVA as shown in Table (7):

Table (7) Analysis ANOVA for the responses of the sample by the variable level of study and specialization

\begin{tabular}{lllllll}
\hline $\begin{array}{l}\text { Field } \\
\text { specialization }\end{array}$ & $\begin{array}{l}\text { Source of } \\
\text { variance }\end{array}$ & SS & DF & MS & F-value & Sig \\
\hline & $\begin{array}{l}\text { Between } \\
\text { groups }\end{array}$ & 44.96 & 2 & 22.48 & & \\
$\begin{array}{l}\text { University } \\
\text { environment }\end{array}$ & Within groups & 14531.289 & 143 & 101.61 & 0.022 & Significant \\
& total & 14576.25 & 145 & 145 & & \\
& $\begin{array}{l}\text { Between } \\
\text { groups }\end{array}$ & 30.338 & 2 & 15.169 & & Insignificant \\
$\begin{array}{l}\text { Faculty } \\
\text { members }\end{array}$ & $\begin{array}{l}\text { Within groups } \\
\text { total }\end{array}$ & 13067.635 & 143 & 91.481 & 0.016 & \\
& $\begin{array}{l}\text { Between } \\
\text { groups }\end{array}$ & 13097.97 & 145 & & & Significance \\
$\begin{array}{l}\text { University } \\
\text { courses }\end{array}$ & 17.961 & 2 & 8.98 & 0.019 & \\
\hline
\end{tabular}




\begin{tabular}{llllll}
\hline & Within & 3709.29 & 143 & 25.93 & \\
groups & 3727.21 & 145 & & \\
total & 662.447 & 2 & 331.223 & 0.583 & Significant \\
& $\begin{array}{l}\text { Between } \\
\text { groups }\end{array}$ & & & & \\
$\begin{array}{l}\text { Overall } \\
\text { total }\end{array}$ & Within & 8121.396 & 143 & 56.793 & \\
& groups & 8783.842 & 145 & & \\
\hline
\end{tabular}

Table (7) shows the following:

1- There are statistically significant differences in the total of the overall fields of the tool. And that there are statistically significant differences attributable to the variable of the academic level except for the field of the faculty members, and the differences are in favor of the first year. The researcher interprets this to the fact that first-year students are still new to university life and they are not familiar with the university environment, subjects, academic staff which differs totally from the environment the experienced in the secondary stage. This finding is consistent with Dumiati (2016).

2- There are statistically significant differences in the existence of educational communication problems in all fields according to the variable of specialization. The researcher attributes this to the students' need for training courses in the field of communication as their GPAs are low compared to students of other specializations whose academic courses include modules related to communication skills. This result agreed with the study (Liaw, 2019) and (Abu- Nair \& Ziadat \& Abu Samyha, 2019), the study of Al-Qabbani and Al-Yahya (2019) and the study of (Dumiati, 2016.)

\section{The study limitations}

1.Objective limits: The research is limited to explaining the reality of practicing the communication skills and their problems among students of Princess Rahma University College at Al-Balqa Applied University in the following fields: the university environment, study materials, and faculty members.

2. Human limitations: The research was limited to the students of Princess Rahma University College at AlBalqa Applied University.

3. Spatial limits: Research is limited to Princess Rahma University College.

4. Time limits: The research was applied during the academic year 2018/2019.

\section{Conclusion:}

The research reached the following results:

- The degree of practicing communication skills among students of Princess Rahma University College came at a moderate degree, and that the most practiced skills are speaking skill and the least understanding and accepting others.

- There are problems in educational communication among students of Princess Rahma University College, that came to a high degree. The field of the university environment came in the first place, and the field of study subjects came second, while the field of faculty members came in the last rank.

- There are statistically significant differences in the degree of educational communication problems among Princess Rahma University College students due to variables gender, academic level, and specialization. 
Al-Omari, J. F. M., (2020). Educational communication skills and their problems among students of Princess Rahma university college at Al-Balqa applied university. Cypriot Journal of Educational Science. 15(5), 1337 - 1353 https://doi.org/10.18844/cjes.v15i5.5172

\section{Recommendations}

The researcher recommends the following:

1- Constructing buildings with wide halls capable of accommodating the increasing number of students and to solve the problems of overcrowding of students in the halls in a manner that is compatible with the appropriate university environment under the standards of accreditation and quality assurance.

2- Providing the library with book events, references, and paper and electronic periodicals.

3- Working to find an academic electronic portal through which the student can communicate with the teaching staff.

4- The necessity of setting a comprehensive strategy to prevent the occurrence of academic problems facing students at the university, and to find appropriate solutions for them, so that the academic level improves for them.

5- Redesigning, implementing, evaluating, and developing university curricula and programs from time to time in the various university majors and good planning for them to become more efficient and effective.

6- Inviting faculty and students to use social media to achieve a greater understanding among students.

7- Conducting more studies on evaluating all elements of the university environment, considering the results of the studies, and transferring them to the implementation stage to improve and develop higher education institutions.

8- Adopting the official social media between the university and students.

\section{References:}

Al-Adra, I., Abu Arqoub, I. (2015). Communication barriers for the University of Jordan students from their point of view. Studies Magazine: Social and Human Sciences. Journal of University of Jordan Volume 42, Supplement 2, pp. 1347-1349.

Al-Balqa Applied University (2018). General Statistics for students registered with the university, Admission and Registration Unit, Salt, Jordan. Al-Khilafi, T. (2013). Communication problems between preparatory year students and faculty members at Al-Jouf University, research published in the Journal of the Faculty of Education - Al-Azhar University, p. 155, part 3, pp. 293-266 Egypt.

Dumiati, S, I.(2016). Academic problems of Taibah University students and their relationship to the level of performance A field study, research submitted to the girl's higher education: dimensions and aspirations, Taibah University, Medina, 4-6 January.

Al-Hariri, R. (2018). Decision-making skills in administrative leadership. Dar Al-Safa, Amman, Jordan.

Hamidat, R. (2009). Rationing and building a scale of communication skills for Jordanian university students. Unpublished Master Thesis, Mutah University, Jordan.

Ibrahim, M., and Othman, A. (2016) Building and codifying the scale of social problems. Journal of Educational Sciences, Cairo University, Vol. 24, No. 3.

Liaw, M.L. (2019). EFL Learners' Intercultural Communication in an Open Social Virtual Environment, Journal of Educational Technology \& Society . 22(2), 38-55.). ,

www.bau.edu.jo

Murtaja, Z. (2013). The scale of educational communication problems, Dar Al-Nazma Educational System, Amman.

Al-Qabbani .A. Al-Yahya .M (2019). The role of social networking sites in enhancing dialogue skills among university students, Journal of Educational Sciences, Islamic University, No. 1, pp. 23-47, Medina, Kingdom of Saudi Arabia. 
Al-Omari, J. F. M., (2020). Educational communication skills and their problems among students of Princess Rahma university college at Al-Balqa applied university. Cypriot Journal of Educational Science. 15(5), 1337 - 1353 https://doi.org/10.18844/cjes.v15i5.5172

Al-Qarni, A. (2007). "Methods and methods of developing the performance of the teaching professor", a symposium on developing faculty members in higher education institutions, college of education. King Saud University, Riyadh.

Al-Shehri, N. (2014). Communication Skills, King Abdulaziz University, Saudi Arabia

Amna, M. (2019). The Social Media Among a Sample Of Students Of Alfashir University -Faculty of Education, Journal of Educational and Psychological Sciences, Volume 10 Issue 1.

Shobaki, A., And Al Sudek, K. (2017). The extent of the professor's practice of educational communication skills from the viewpoint of students of the Faculty of Arts in Misurata. Journal of the Faculty of Arts, Misurata University.

Shuqair, R. (2018) The use of social networks and their relationship to some psychological problems among students of the Faculty of Education at the University of Damascus. Al-Baath University Journal for Humanities. Volume 89, No. 4, Al-Baath University, Syria, pp. 89-138.

Ziadat, A., Abu-Nair, N., Abu Sameha, M. (2019).Mechanisms and Development Strategies for Teaching Thinking to Move the Role of Jordan Universities as the Product of the Think Tank from the Faculty Members Point of View. Journal of Instructional Psychology. Jun2011, Vol. 38 Issue 2, p63-74. 12p. 